\title{
Study on synthesis of (2S,3S)-2-methyl-3-((triethylsilyl)oxy)pentanal
}

\author{
Shenkun Yang ${ }^{1, a}$, Tianxiang $X u^{1, b}$, Shuangping Huang ${ }^{1, c_{*}}$ and Xiaoji Wang ${ }^{1, d_{\star}}$ \\ ${ }^{1}$ School of Pharmacy, Jiangxi Science and Technology Normal University, Jiangxi, 330013, China \\ a470416898@qq.com, b3059859608@qq.com, ${ }^{\text {c*}}$ 185544590@qq.com, ${ }^{d * 13767101659 @ 163 . c o m ~}$
}

Keywords: (2S,3S)-2-methyl-3-((triethylsilyl)oxy)pentanal, actinoallolide A, Evans aldol, L-Phenylalanine, synthesis.

\begin{abstract}
The C19-C23 fragment (9) of the anti-trypanosomal natural product actinoallolide A was prepared via an elegant stereo-controlled route. We installed the chiral center at C20 through a standard Evans aldol reaction, and protected the secondary hydroxyl group via a silylanization.
\end{abstract}

\section{Introduction}

Human African Trypanosomiasis and American Trypanosomiasis are serious diseases affecting human health [1-2]. Several months ago, Masato Iwatsuki and coworkers isolated actinoallolide A-E from endogenous strains Actinoallomurus fulvus MK10-036 [3]. These novel natural products showed prominent activity against trypanosomiasis combined with a low toxicity compared with other clinic drug molecules [4-5]. Particularly, actinoallolide A was promising to become the lead cmpound of trypanosomiasis and its related diseases. Limited by low natural content, further biological testing and research of actinoallolide family was encumbered. Total synthesis is indispensable for preparing analogs to gain deeper insight into the mode of action and the pharmacologically active moieties of the molecule.

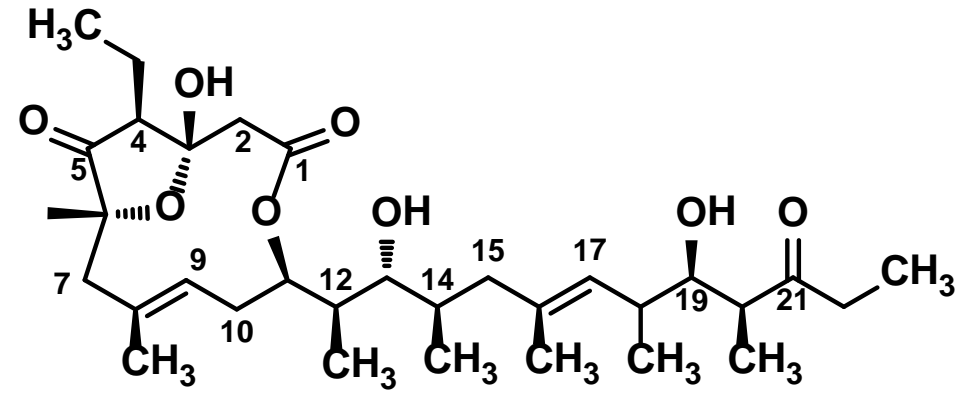

Fig. 1 Structure of actinoallolide A (1)

Structurally, actinoallolide A possesses a macrolacone, 11 stereocenters and 5 chiral hydroxyl groups. These structural characteristics also make the total synthesis of the molecule have great challenge and academic significance. Macrolactones contaning 12-membered ring has excellent biological activity like anti-bacterial [4] and anti-cancer [5]. Thus, total synthesis of actinoallolide A and its analogues has significant value on looking for new medicinal active compounds.

As shown in Fig. 2, our synthetic approach to (2S,3S)-2-methyl-3-((triethylsilyl)oxy)pentanal (9) is via a seven-step route. Inexpensive commercial product L-phenylalanine (2) was initially reduced to alcohol (3), which was then converted to thiazolidinethione (4). Amide (5) could be obtained in high yield via a lysine propionylation of thiazolidinethione (4). An Evans aldol reaction between (5) and (6) proceeded in the presence of titanium tetrachloride and triethylamine to produce trans alcohol (7). After protected though a silylanization with chlorotriethylsilane, the secondary alcohol (7) was reduced to (2S,3S)-2-methyl-3-((triethylsilyl)oxy)pentanal (9). The further study towards to actinoallolide A was going on in our lab from compound (9). 


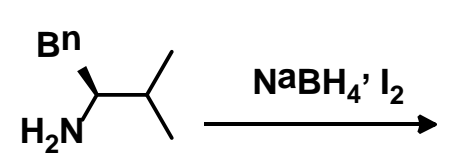

(2)<smiles>N[C@@H](Br)CO</smiles>

(3)<smiles>S=C1NC(Br)CS1</smiles><smiles>CCC(=O)I</smiles><smiles>CCC(O[Se])C(C)C(=O)N1C(=S)SCC1Br</smiles>

(8)

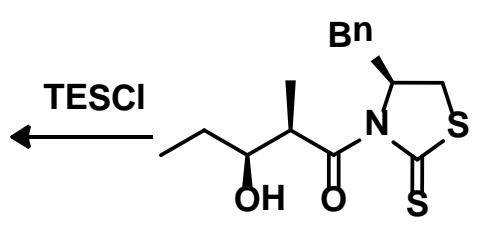

(7)<smiles>CCC(=O)C=CC(=O)O</smiles>

(a)

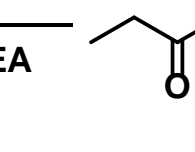

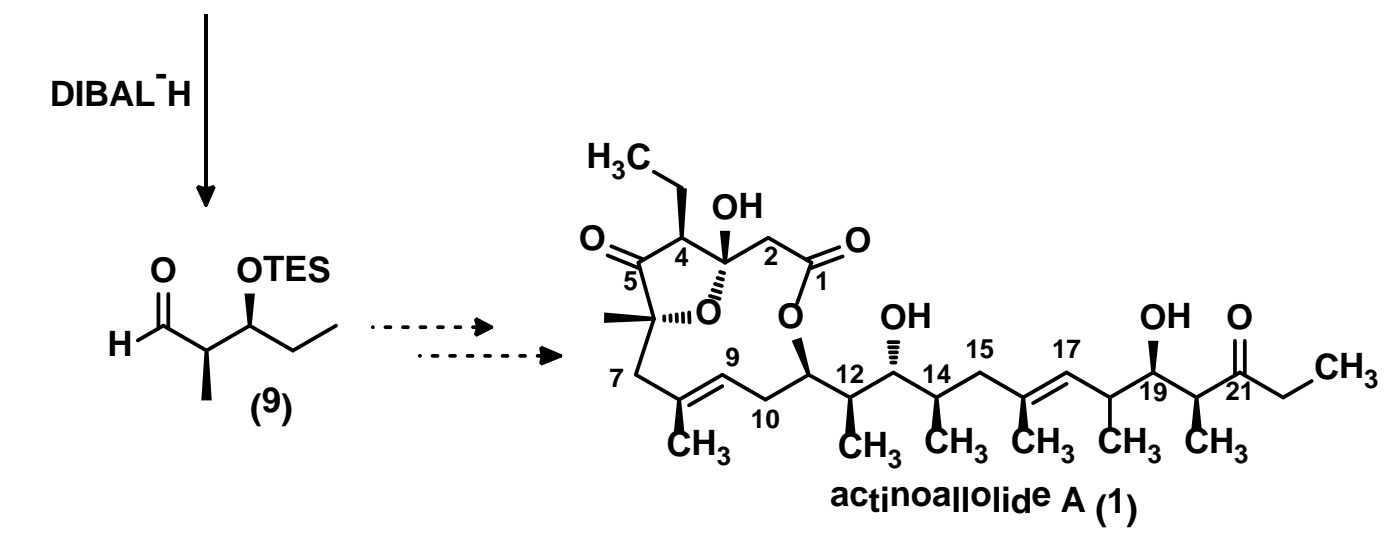

Fig. 2 Synthesis of key intermediate of actinoallolide A (2S,3S)-2-methyl-3-((triethylsilyl)oxy)pentanal (9)

\section{Experimental}

NMR spectra were recorded on a BRUKER AV-400MHz NMR (Nuclear Magnetic Resonance). The chemical shifts are recorded relative to an internal standard or relative to chloroform. All coupling constants, J, are reported in Hertz. All solvents are refined by standard method.

1.1 (S)-2-amino-3-phenylpropan-1-ol (3). To a solution of L-phenylalanine (10 g, $60.54 \mathrm{~mol})$ in $140 \mathrm{~mL}$ THF was added $\mathrm{NaBH}_{4}(5.73 \mathrm{~g}, 151.46 \mathrm{mmol})$ and the mixture was cooled to $0{ }^{\circ} \mathrm{C}$. A solution of iodine $(18.4 \mathrm{~g}, 72.66 \mathrm{mmol})$ in $60 \mathrm{~mL}$ THF was added dropwise. After adecreasing gas evolution the mixture was heated to reflux for $18 \mathrm{~h}$. The flask was cooled to $0{ }^{\circ} \mathrm{C}$ and $\mathrm{MeOH}(24$ $\mathrm{mL}$ ) was added cautiously until the mixture became a clear solution. The resultingsolution slowly warmed to rt over $1 \mathrm{~h}$ and stirred at rt further $45 \mathrm{~min}$. The solvent was removedunder reduced pressure and the white residue was dissolved in $126 \mathrm{~mL}$ of $20 \%$ aq. $\mathrm{KOH}$ andstirred at rt for $4 \mathrm{~h}$. The reaction mixture was extracted with $\mathrm{CH}_{2} \mathrm{Cl}_{2}(3 \times 200 \mathrm{~mL})$ and dried over $\mathrm{Na}_{2} \mathrm{SO}_{4}$, and concentrated on a rotary evaporator. Dry Column Vacuum Chromatography (DCVC) using $\mathrm{SiO}_{2}$ and washing with EtOAc afforded (S)-2-amino-3-phenylpropan-1-ol (9.06 g, 59.9 mol, 99\%); 1H NMR (400 MHz, $\left.\mathrm{CDCl}_{3}\right) \delta$ 2.49-2.56(m, $\left.1 \mathrm{H}\right), 2.78-2.83(\mathrm{~m}, 1 \mathrm{H}), 3.08-3.16(\mathrm{~m}, 1 \mathrm{H}), 3.36-3.42(\mathrm{~m}$, $1 \mathrm{H}) 3.61-3.66(\mathrm{~m}, 1 \mathrm{H}), 7.18-7.37(\mathrm{~m}, 5 \mathrm{H})$.

1.2 (S)-4-benzylthiazolidine-2-thione (4) .To a solution (S)-2-amino-3-phenylpropan-1-ol (3) (15 mmol) in $75 \mathrm{~mL}$ of aqueous $1 \mathrm{~N}$ potassium hydroxide was added $\mathrm{CS}_{2}(75 \mathrm{mmol}, 4.5 \mathrm{~mL})$. The reaction mixture was stirred at $100{ }^{\circ} \mathrm{C}$ (bath at $110{ }^{\circ} \mathrm{C}$ and an efficient reflux condensation) for $16 \mathrm{~h}$. After cooling to room temperature, the reaction mixture was extracted with dichloromethane ( 2 x 75 $\mathrm{mL}$ ). The combined organic layers were dried over anhydrous $\mathrm{Na}_{2} \mathrm{SO}_{4}$ and then evaporated under reduced pressure. The crude product was further purified; $\left.1 \mathrm{H} \mathrm{NMR} \mathrm{(400} \mathrm{MHz}, \mathrm{CDCl}_{3}\right) \delta 8.36$ (bs, 
1H), 7.32 (m, 2H), $7.26(\mathrm{~m}, 1 \mathrm{H}), 7.18(\mathrm{~m}, 2 \mathrm{H}), 4.46$ (dd, $J=7.5,15.0 \mathrm{~Hz}, 1 \mathrm{H}), 3.50$ (dt, $J=7.9$, $11.5 \mathrm{~Hz}, 1 \mathrm{H}$ ), 3.25 (dt, $J=7.2,11.5 \mathrm{~Hz}, 1 \mathrm{H}), 3.04$ (m, 1H), 2.93 (m, 1H).

1.3 (S)-1-(4-benzyl-2-thioxothiazolidin-3-yl)-propan-1-one (5). To a solution of thione (4) (1.30 g, $6.21 \mathrm{mmol})$ dissolved in $\mathrm{CH}_{2} \mathrm{Cl}_{2}(36 \mathrm{~mL})$ was added triethylamine $(1.04 \mathrm{~mL}, 7.45 \mathrm{mmol})$ and 4-dimethylaminopyridine $(0.15 \mathrm{~g}, 1.23 \mathrm{mmol})$ sequentially at $0{ }^{\circ} \mathrm{C}$. Freshly distilled propionyl chloride $(0.70 \mathrm{~mL}, 8.07 \mathrm{~mol})$ in $\mathrm{CH}_{2} \mathrm{Cl}_{2}(75 \mathrm{~mL})$ added dropwise over $1 \mathrm{~h}$. After stirring at $\mathrm{rt}$ for 3 h, satd. $\mathrm{NH}_{4} \mathrm{Cl}(75 \mathrm{~mL})$ was added and the mixture was extracted with $\mathrm{CH}_{2} \mathrm{Cl}_{2}(3 \times 150 \mathrm{~mL})$. The organic layers were combined, washed with satd. $\mathrm{NaHCO}_{3}(75 \mathrm{~mL})$ and brine $(75 \mathrm{~mL})$, dried with $\mathrm{Na}_{2} \mathrm{SO}_{4}$, and concentrated on a rotary evaporator. Recrystallization from $\mathrm{CH}_{3} \mathrm{CN}$ afforded pure (5) (1.55 g, 94\%); 1H NMR (400 MHz, $\mathrm{CDCl}_{3}$ ) $\delta 7.30$ (m, 5H), 5.40 (ddd, $J=3.8,7.3,10.9 \mathrm{~Hz}, 1 \mathrm{H}$ ), $3.41(\mathrm{~m}, 2 \mathrm{H}), 3.22$ (dd, $J=3.7,13.2 \mathrm{~Hz}, 1 \mathrm{H}), 3.10(\mathrm{qd}, J=7.1,18.1 \mathrm{~Hz}, 1 \mathrm{H}), 2.87$ (d, $J=11.5 \mathrm{~Hz}$, 1H), 1.21 (t, $J=7.2 \mathrm{~Hz}, 3 \mathrm{H})$;

1.4 (2R,3S)-1-((S)-4-benzyl-2-thioxothiazolidin-3-yl)-3-hydroxy-2-methylpentan-1-one (7). To a solution of acylated auxiliary S3 $(7.1 \mathrm{~g}, 27 \mathrm{mmol})$ was dissolved in $\mathrm{CH}_{2} \mathrm{Cl}_{2}(215 \mathrm{~mL})$. After cooling to $0{ }^{\circ} \mathrm{C}, \mathrm{TiCl}_{4}(3.1 \mathrm{~mL}, 0.028 \mathrm{mmol})$ was added over $5 \mathrm{~min}$. $\mathrm{EtN}^{\mathrm{i}} \operatorname{Pr}_{2}(5.15 \mathrm{~mL}, 30 \mathrm{mmol})$ was added. The mixture was stirred for $15 \mathrm{~min}$ at $0{ }^{\circ} \mathrm{C}$ and then cooled to $-78{ }^{\circ} \mathrm{C}$. Propyl aldehyde (6) $(2.3 \mathrm{~mL}, 30 \mathrm{mmol})$ was added and the mixture was warmed to $0{ }^{\circ} \mathrm{C}$ over $2 \mathrm{~h}$. Satd. $\mathrm{NaHCO}_{3}(50$ $\mathrm{mL}$ ) was added cautiously and then extracted with $\mathrm{CH}_{2} \mathrm{Cl}_{2}(3 \times 300 \mathrm{~mL})$. The organic layers were combined, washed with satd. brine $(50 \mathrm{~mL})$, dried with $\mathrm{Na}_{2} \mathrm{SO}_{4}$, and concentrated on a rotary evaporator. Flash chromatography with a gradient from hexanes to $1: 1$ hexanes/EtOAc afforded pure (7) (15.58 g, 90\%); 1H NMR (400 MHz, $\left.\mathrm{CDCl}_{3}\right) \delta 7.33(\mathrm{~m}, 2 \mathrm{H}), 7.27(\mathrm{~m}, 3 \mathrm{H}), 5.36$ (ddd, $J=$ 4.1, 7.2, $10.8 \mathrm{~Hz}, 1 \mathrm{H}), 4.63$ (qd, $J=2.0,7.1 \mathrm{~Hz}, 1 \mathrm{H}), 3.97$ (m, $1 \mathrm{H}), 3.36$ (dd, $J=7.2,11.5 \mathrm{~Hz}, 1 \mathrm{H}$ ), 3.24 (dd, $J=4.0,13.2 \mathrm{~Hz}, 1 \mathrm{H}), 3.04$ (dd, $J=10.4,13.1 \mathrm{~Hz}, 1 \mathrm{H}), 2.88$ (d, $J=11.6 \mathrm{~Hz}, 1 \mathrm{H}$ ), 2.79 (d, $\mathrm{J}=2.9 \mathrm{~Hz}, 1 \mathrm{H}), 1.61(\mathrm{~m}, 1 \mathrm{H}), 1.45(\mathrm{~m}, 1 \mathrm{H}), 1.18(\mathrm{~d}, J=7.1 \mathrm{~Hz}, 3 \mathrm{H}), 0.97$ (t, $J=7.4 \mathrm{~Hz}, 3 \mathrm{H})$.

1.5 (2R,3S)-2-methyl-1-(4-(3-phenylpropoxy)-2-thioxothiazolidin-3-yl)-3-((triethylsilyl)oxy) pentan-1-one (8). To a solution of ketone (7) $(1.10 \mathrm{~g}, 3.4 \mathrm{mmol})$ in $\mathrm{C} 2 \mathrm{H} 2(30 \mathrm{~mL})$ was added imidazole (0.926g, $13.6 \mathrm{mmol})$. The mixture was then cooled to $0{ }^{\circ} \mathrm{C}$. Chlorotriethylsilane was added dropwise. Satd. $\mathrm{NaHCO}_{3}(30 \mathrm{~mL})$ was added cautiously and then extracted with $\mathrm{CH}_{2} \mathrm{Cl}_{2}(3 \times$ $50 \mathrm{~mL}$ ). Flash chromatography with a gradient from hexanes to 100:1 hexanes/EtOAc afforded pure (8) (1.23g, 83\%); 1H NMR (400 MHz, $\mathrm{CDCl}_{3}$ ) $\delta 7.30$ (m, 5H), 5.40 (ddd, $J=4.1,7.2,10.8 \mathrm{~Hz}, 1 \mathrm{H}$ ), 4.63 (qd, $J=2.0,7.1 \mathrm{~Hz}, 1 \mathrm{H}), 3.97(\mathrm{~m}, 1 \mathrm{H}), 3.36$ (dd, $J=7.2,11.5 \mathrm{~Hz}, 1 \mathrm{H}$ ), 3.24 (dd, $J=4.0,13.2$ Hz, 1H), 3.04 (dd, $J=10.4,13.1 \mathrm{~Hz}, 1 \mathrm{H}), 2.88$ (d, $J=11.6 \mathrm{~Hz}, 1 \mathrm{H}), 2.79$ (d, $J=2.9 \mathrm{~Hz}, 1 \mathrm{H}), 1.61$ (m, 1H), $1.45(\mathrm{~m}, 1 \mathrm{H}), 1.18(\mathrm{~d}, J=7.1 \mathrm{~Hz}, 3 \mathrm{H}), 0.8-1.0(\mathrm{~m}, 12 \mathrm{H}), 0.7$ ( t , 6H).

1.6 (2S,3S)-2-methyl-3-((triethylsilyl)oxy)pentanal (9). The solution of (8) (0.2 g, $0.45 \mathrm{mmol})$ in $\mathrm{C} 2 \mathrm{H} 2(5 \mathrm{ml})$ was cooled to $-78{ }^{\circ} \mathrm{C}$.Then the diisobutylaluminium hydride (DIPEA-H, $1.5 \mathrm{~mol} / \mathrm{L}$ ) (0.45 mL, $0.675 \mathrm{mmol}$ ) was added dropwise. The mixture was stirred for $30 \mathrm{~min}$, then quenched with $\mathrm{MeOH}(0.5 \mathrm{~mL})$ and potassium sodium tartrate $(5 \mathrm{~mL})$.Dry Column Vacuum Chromatography (DCVC) using $\mathrm{SiO}_{2}$ and washing with a gradient from hexanes to 100:1 hexanes/EtOAc afforded pure (8) (0.09g, 87\%); 1H NMR (400 MHz, $\left.\mathrm{CDCl}_{3}\right) \delta 9.77(\mathrm{~s}, 1 \mathrm{H}), 4.06(\mathrm{t}, 1 \mathrm{H}), 2.46(\mathrm{~m}, 1 \mathrm{H}), 1.60$ (m, 1H), 1.45 (m, 1H), 1.07 (d, 3H), 0.8-1.0 (m, 12H), 0.7 (t, 6H).

\section{Acknowledgement}

We gratefully thank the National Natural Science Foundation of China (No.21562020), Science a nd Technology Research Projects of the Education Department of Jiangxi Province (No. GJJ14579), Science and Technology Plan Project of Jiangxi Province (No. 20142BBE50006), Scientific Resear ch Fund of Jiangxi Provincial Education Department (No. KJLD12036), Training Fund for Excellen t young scientist of JiangXi Province (No. [2013]138) for the funding support. 


\section{References}

[1] R. Viotti, C. Vigliano, B. Lococo, Ann. Intern. Med. 144 (2006) 724-734.

[2] P. J. Hotez, E. Dumonteil, L. Woc-Colburn, J. A. Serpa, S. Bezek, M. S. Edwards, C. J. Hall-mark, L. W. Musselwhite, B. J. Flink, M. E. Bottazzi, Plos. Neql. Trop. Dis. 6 (2012) e1498.

[3] I. Masato, Y. Inahashi, I. Aki, Organic letters. 17 (2015) 864-867.

[4] I. Yuki, I. Masato, I. Aki, M. Atsuko, H. Tomoyasu, O. Jun, S. Toshiaki, P. Watanalai, T. Yoko, T. Marcel, O. Kazuhiko, Ō. Satoshi, Org. Lett. 17 (2015) 864-867.

[5] E. Chatelain, J. Biomol. Screen.20 (2015) 22.

[6] J. Clayton, Nature. 465 (2015) S12.

[7] M. N. Donin, J. Pagano, J. D. Dutcher, C. M. Mckee, Antibiot. Ann. 1 (1953-1954) 179.

[8] Y. Takayasu, K. Tsuchiya, T. Aoyama, Y. J. Sukenaga, Antibiot. 54 (2001) 1111. 